\title{
BUILDING CONSUMER ORIENTED STRATEGY FOR A SPECIALISED REGIONAL STORE CHAIN
}

\author{
AnNa Zhigalova ${ }^{1}$ \\ University of Latvia (Latvia)
}

\begin{abstract}
The research was made to identify how the retail strategy of a specialized regional chain should be reshaped in order to meet consumer requirements and satisfy their needs, compete against different store formats and maximize business efficiency. The analysis was made to identify alcoholic beverages consumption and buying habits, reasons and choice criteria of stores, perception, image and expectations of a specialized alcohol store. Also several business development ideas were tested, such as change of the assortment and evaluation of new concept of a retail chain. Sampled respondents were from 18 to 60 years old, who have bought alcoholic beverages last three months. Survey revealed that that consumer's choice criteria of a retailer format differs considering different buying occasions and several dominant 'must-haves' were identified for a specialized retail store, such as location, assortment, price level of a best sellers and image of a store.
\end{abstract}

KEYWORDS: consumer behavior, retail, strategy.

JEL CODES: L66; M31; C81

\section{Introduction}

The structure of food retailing has changed dramatically over the last few decades. In previous years, main retail formats were traditional markets or grocery stores. Consumers purchase almost everything there including fresh fruit and vegetables, meat and fish and all other household supplies like dry food, bread, detergents, stationery and toys.

Since the 1990's, the food retailing industry has experienced tremendous growth. Modern retail outlets, such as supermarkets and hypermarkets now are dominating the local retail food trade. With new retail outlets emerging, consumers are reviewing where they will do shopping.

The main problem in building long term sustainable strategy for a retail chain is in predicting how rapid change of environmental conditions (economical, social, legal and other circumstances) will impact consumer behavior, particularly - store choice. As the retail environment is becoming tougher and more competitive and consumers are growing more sophisticated, retailers make every effort to draw new customers to their stores and to encourage existing customers to keep patronizing their stores. However, consumers have different and diverse reasons in terms of choosing a particular store over alternative stores. Understanding these reasons in store choice is a formidable challenge. Moreover, retail market value is not growing what makes competitive push higher as market participants can grow business only by taking market shares from each other. Scandinavian modern trade key accounts that entered retail market of Baltic Region have very strong competitive advantages, such as centralized resources, long term experience and gained knowledge, heritage, lower costs due to various consolidations, better merchandising and synergy from collective knowledge

Anna Zhigalova - University of Latvia, Faculty of Economics and Management, applicant for doctoral studies. Scientific interests: marketing research, customer loyalty.

E-mail: anna.zhigalova@gmail.com

Tel.: +37129548343. 
(Efficient Consumer Response project, for example). Heavy marketing investments that are unavailable for majority of local players ensures strong superiority for those market players. Smaller regional retailers also have definite advantages, such as location, fresh stocks due to lower pipelines, lower fixed costs, local knowledge and mentality, accustomed service, etc., but they are much more limited in all resources to resist retail market reshaping in favour of modern trade.

Alongside the development of the retail industry, the behavior of consumers has also changed experiencing dramatic shift in their lifestyle, which impacts on the way they purchase, including such factors as increase in personal disposable income, urbanisation and greater awareness of safety and quality issues, changes in diet.

In these tough economic times, it is important to adjust strategy to fast changing consumer requirements and needs in order to keep loyal consumers and to attract new ones. Competition is growing permanently along with the need to cut costs in order to be more efficient and maximise profitability.

The aim of the research was to identify how the retail strategy of a specialized regional chain should be reshaped in order to meet consumer requirements and satisfy their needs, compete against different store formats and maximize business efficiency.

The objective of the research was to identify which factors are most influential in the consumers' choice of a retail outlet when purchasing alcohol beverages and test several proposed concepts and strategies. It was made for a specialized retail store chain that belongs to "Latvijas Balzams" production and that consists of 55 specialised convenience stores in Latvia and 20 - in Lithuania.

Research method: both quantitative and qualitative methods were used. Qualitative study was made in 5 focus groups, 5 respondents in each, equally men and women who have bought alcoholic beverages during last 3 months in $L B$ and competitor stores, Latvian and Russian speaking. Quantitative survey targeted 18-60 years old residents of cities that have bought alcoholic beverages in the last three months. Sample size was 402 respondents.

\section{Consumer's consideration set choosing the retail store}

An important research stream relevant to this paper is research on store choice. Store choice is one of the heavily studied areas in marketing (e.g., Aaker, Jones, 1971; Hisrich, Dornoff, Kernan, 1972; Hortman et al., 1990; Kahn, Schmittlein, 1989; Kau, Ehrenberg, 1984; Monroe, Guiltinan, 1975; Pessemier, 1980; Popkowski Leszczyc, Sinha, Timmermans, 2000; Solgaard, Hansen, 2003; Uncles, Hammond, 1995) and geography (e.g., Moore, 1990; Wrigley, Dunn, 1988).

In the positioning of grocery retail stores, price, apparently plays the decisive role, and a much more important role than in the positioning of products and brands. Indeed, $90 \%$ of all retail advertising in Europe is price related, and $70 \%$ is exclusively on price (Corstens, Corstens, 1995). This seems to indicate that store choice primarily is motivated by utility considerations rather than by hedonic considerations and that grocery shopping is a functional activity, where consumers' perception of price plays the major role. In a study of consumers' perceptions of grocery retail chains Solgaard (2000) was observed that although discount chains are rated very poorly compared to other supermarket formats on a whole range of store values except one, namely, good prices (in all 21 value aspects were rated), discount chains at the same time are growing and gaining market share.

Store location has received much attention in research on store choice and for good reasons. Bell et al. (1998) refer to industry research in the US that indicates that location explains up to $70 \%$ of the variations in the choice of grocery store. Refer also to Stanley and Sewall (1976), Verhallen and de Nooij (1982), Engstram and Larsen (1987), and Arnold et al. (1983), for the importance of the location or distance variable in store choice. The number and nature of neighboring stores may also be an important factor in the store choice. May (1981) argued that consumers tend to make more of their patronage decisions based on the shopping complex instead of the individual store. Hansen and Weinberg's (1979) findings concerning choice of bank outlet support this argument; see also Gripsrud and Horverak (1986). The point is of course that the 
ease with which the consumer can get from one facility to another type of facility is essential in explaining her choice of store.

Service outputs also provide input for the positioning. Although an individual consumer alone might perform the chore of grocery shopping, it is the needs of the household that would be satisfied by this activity. Thus household size, and number and age of children will influence store choice behavior. Also, household characteristics, such as income, working hours and availability of a car put restrictions on, as well, as opportunities, for what is feasible for the household in terms of grocery purchasing.

The theoretical framework for specifying the process that leads a consumer to choose a certain store from her consideration set of stores is drawn from the theories of consumer behavior developed in marketing (e.g., Blackwell et al., 2001) and from the microeconomic theory of the consumer (e.g., Deaton and Muellbauer, 1980). In line with these theories a consumer is assumed to form relative judgments about the available stores based on her/his attitudes towards the stores and on situational considerations. This enables him to express his behavioral intentions in terms of (perceived) utility assigned to each store.

Situational considerations are a function of the consumer's awareness of events (at the moment of choice) and/or the need to search for information that may affect her choice behavior. Some examples are: upcoming usage situations that require specific purchases, (Engstram, Larsen, 1987), pressure from competing retailers in terms of promotional offers that must be evaluated and shopping activities carried out in combination with other non-domestic activities, creating a possible need for evaluation of unknown shopping environments, etc. Thus the utility assigned to a particular store could also be depicted as a function of store attributes, personal characteristics including relevant household characteristics and situational considerations.

Most consumers have patterns of grocery shopping which involve more than one store, (Corstens, Corstens, 1995). They regularly visit two or more stores simply because they arrange shopping trips from different geographical bases (e.g., home and work, or other non-domestic activities). Likewise different stores may serve different roles, either by shopping occasion (e.g., major shopping trip, lunch hour fill-up) or by specialty (e.g., vegetables, meat, discount, etc.). In addition, some consumers may visit stores on a regular repertoire basis, both to review prices in competing stores and because they enjoy a sense of variety. Still others may visit different stores looking for good values and also in an attempt to track down the items they prefer most. Finally individuals within a household may have different preferences for particular stores.

For these reasons a consumer's consideration set of visited stores may change from one purchase occasion to another within a short time period such as a week or even a day. A more regular pattern of store choice may, however, emerge over a longer time.

In a paper "A hierarchical Bayes model of choice between supermarket formats" Solgaard et al. considered three formats: conventional supermarkets characterized by high-low pricing, wide assortment and some service, discount stores characterized by every-day-low-pricing, narrow assortment and no service, and hypermarkets, characterized by a pricing policy somewhat in between the two other formats, large assortment and some service.

\section{Marketing Mix influence on consumer's choice of a retail store}

Various academic and commercial studies show that the seven Ps of marketing are critical in determining consumer choice of store. According to Engel, Blackwell and Miniard (1995) there are 10 determinant attributes of store choice: location, nature and quality of assortment, price, advertising and promotion, sales personnel, services offered, physical store attributes, nature of store clientele, store atmosphere, and post transaction service and satisfaction. In chronological order of importance Bates and Gabor (1987) found the following to be important in influencing shoppers' choice of store: cheap prices, fair prices, good value, convenience, nearest to home and workplace, cleanliness, good layout, good quality, variety and choice, satisfaction, dividend, principle, member, employee, and delivery service.

Starting with the most important, Euromonitor (1986) found the following 21 items were important 'things liked about main store'. These are clean and hygienic, extensive range, store layout, good value, good parking, quality of foods, cheap or low prices, opens late, good fresh fruit and vegetables, spacious, easy 
walking distance, good fresh meat, selection of frozen food, efficient checkout service, in-store bakery, own label products, chilled/ready foods, range of non foods, good fresh fish, carry out service, and other factors. In 1998 a British marketing research firm, Mintel, found that the following 13 factors were important in influencing consumer choice of store for main grocery shopping in Britain. Starting with the most important these factors are: quality of products, location/easy to get to, attractive prices, wide range of products, measures to ease queues at checkout, fresh food service counter (e.g. deli, fish), longer opening hours, good own label range, cash point facilities, express checkouts, customer loyalty cards, cash back facility, and financial services (Mintel, 1998).

The consumer research Consumer Watch (2011) reveals that top factors influencing choice of store are: price: $54 \%$ of consumers used their store because they liked the price offer; layout: $48 \%$ of consumers used their store because they knew the layout; food choice: $44 \%$ of consumers used their store because of the choice of food; location: $34 \%$ of consumers used their store because it was the closest to them/easiest to get to.

Whilst price was the main deciding factor for less affluent consumers, it also plays an important role amongst those for whom money is less of an issue. The importance of a consistent store layout was emphasised. Once people had acquired a good knowledge of where products could be found within a store it seemed to play a considerable role in maintaining customer loyalty. Changes to the layout (perceived or real) were guaranteed to wind up shoppers, because they interrupted their shopping pattern and were thought to be done primarily to make consumers go down every aisle.

Other aspects that come into the decision making process once these fundamentals are met are: promotions on offer, store not being too large, opening hours, own brand products, loyalty cards available.

This shows that store choice is based on a combination of providing the right product offer in terms of price and choice and the convenience of the shopping trip in terms of finding the products and the ease of getting to a store.

\section{Empirical Research Results}

\subsection{Empirical Research Objectives}

Major business objective was to develop clear, differentiated retail strategy for Lithuania and Latvia based on consumer shopping habits (i.e. one-stop shopping vs. specialized stores) and needs (i.e. price, convenience, assortment), while taking into account current market perception and position of stores defining strong competitive advantages of Latvijas Balzams ( $L B)$ stores vs. competition.

Major research tasks were to define alcoholic beverages consumption and buying habits of consumers; persons responsible for the alcohol purchase; reasons and choice criteria of the stores (Latvijas Balzams (LB), Rimi, Maxima, Eirovins in Latvia and Alco Bravo, Gero Vyno Parduotuve, Filipopolis, Centrine Gerimu Isparduotuve, Vynoteka, Maxima and Rimi - in Lithuania), perception and expectations of $L B$ image, associations and connection of "Latvijas Balzams" production image with $L B$ stores, changes of the assortment, $L B$ and competitor's advantages and disadvantages, evaluation of new concept of $L B$.

Specific research objectives were to define how do consumers buy alcohol (do they usually do one stop shopping vs. going to specialized alcohol stores, explore occasions where they would do one vs. the other, would they ever buy food in one store and go for a alcohol in another (wine vs spirits), etc); what factors are driving their store choice (is it alcohol related factors or other factors such as food and alcohol is secondary consideration; do they buy different alcohol segments, sizes, amounts, packaging based on store format; what is convenience); who is responsible for the alcohol purchase (are wife's the gatekeepers for men or do men shop themselves, do men shop for women or do women purchase themselves); why do consumers shop at $L B$ stores / Eurovins / Rimi / Maxima; For what occasions are they shopping; discuss concrete situations of purchase and consumption of the purchases (i.e. Friday Party vs. immediate consumption); what is the image of $L B$ stores, how it is tied to the $L B$ company image; are the stores seen as factory outlet stores or liquor 
stores under the company logo; ranking of general alcohol purchase motivators vs. purchase motivators for choosing $L B$ and discuss what $L B$ does well and could improve. For non-consumers please discuss reasons for not shopping at $L B$ stores. Probe importance of customer service and how import it is in their decision making; Probe also into importance of product knowledge by sales staff. Present ideas of new $L B$ concept stores and get reactions.

\subsection{Empirical Research Method}

Both quantitative and qualitative methods were used. Qualitative study was made in 5 focus groups, 5 respondents in each, equally men and women who have bought alcoholic beverages during last 3 months in $L B$ and competitor stores, Latvian and Russian speaking.

Quantitative survey targeted 18-60 years old residents of cities that have bought alcoholic beverages in the last three months. Sample size was 402 respondents. Sampling: random - quota sampling method. Quota on residence - 200 interviews in Riga and 200 interviews in other cities. Survey process: interviews were performed by 18 interviewers who were trained and instructed for the particular survey.

\subsection{Empirical Research Findings}

Awareness map (see figure 1) shows good scoring for $L B$ stores. They are located significantly above average, in well known and respected segment, among other major market leaders.

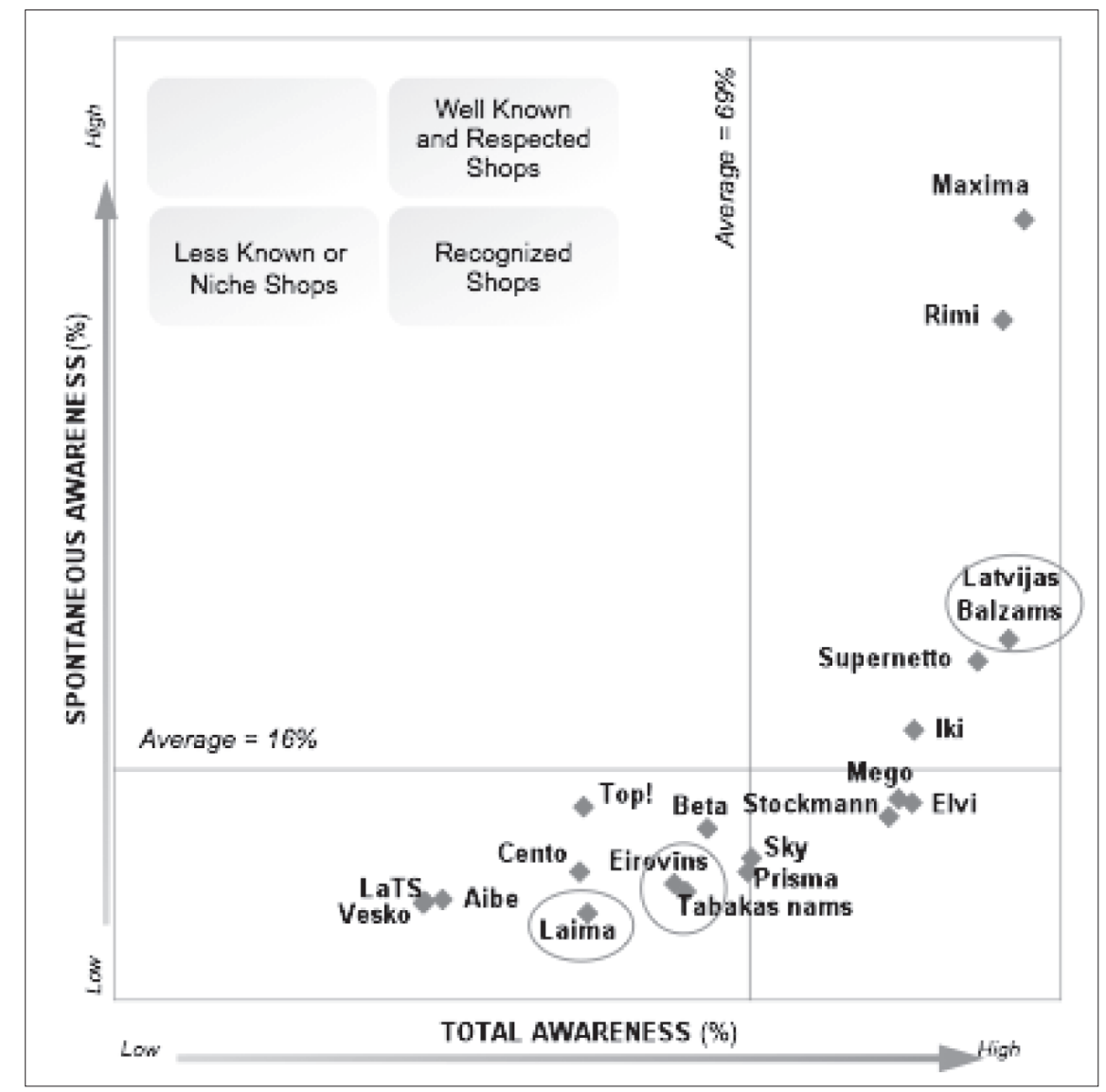

Figure 1. Shop Awareness Map

Source: TNS Research (2011) 
According to spontaneous awareness $L B$ is in the third place, while the total awareness level is very high - the same as for leading retailers - Rimi and Maxima.

When asked to tell, why do they choose their main place for buying alcoholic beverages, respondents mainly say it is because of the location. It means that a wide chain of stores (which people can find on their way to or from home) is the one with higher potential for being chosen. The next aspect is the price and here regular/ different promotion campaigns are preferred. The assortment is the third factor of choice.

The most popular special offer is discount for every purchase. The majority of people irrespective of their profile support it as is illustrated in Figure 2. A similar proportion of customers support loyalty cards that give a special discount.

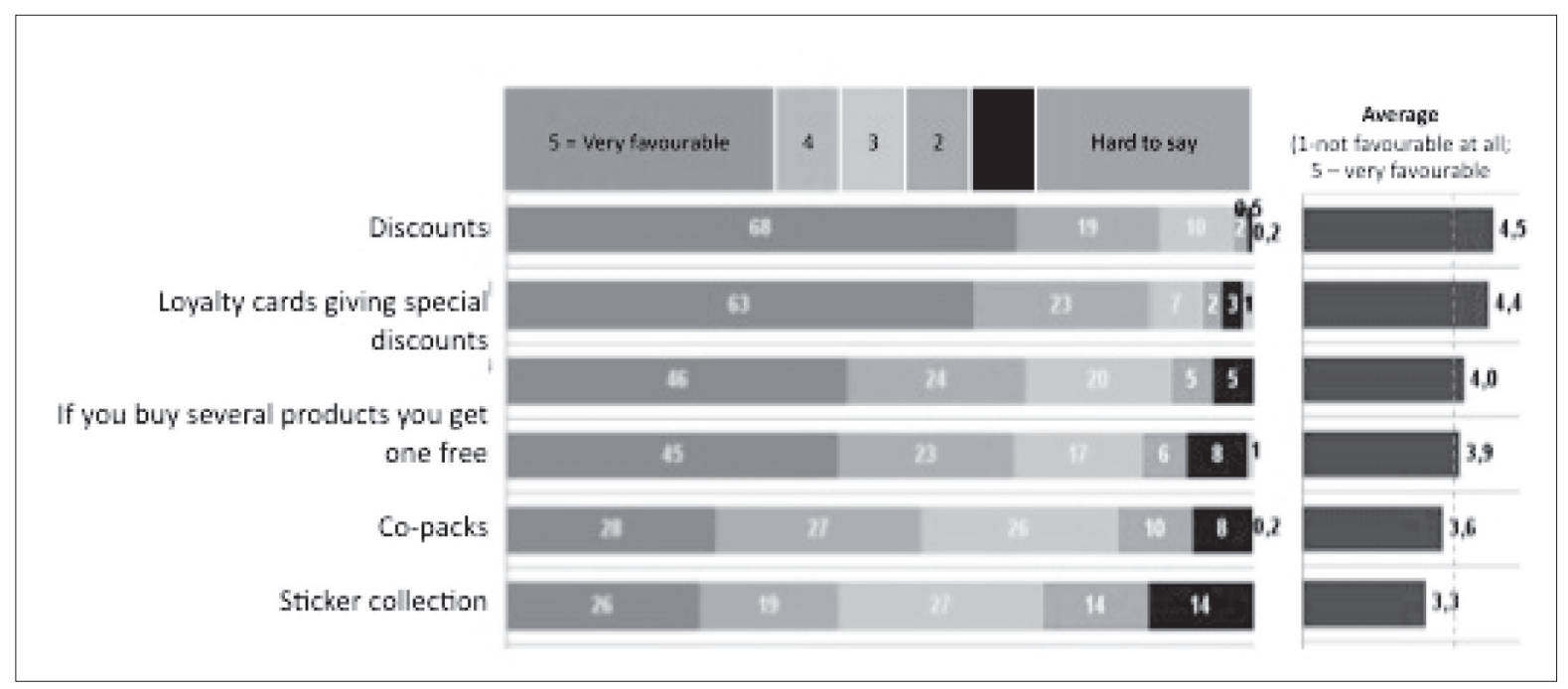

Figure 2. Factors influencing choice of a specialized retailer by different consumer segments

Source: TNS Research (2011)

Women, people with lower income and those, who spend up to 5Ls for alcoholic beverages on average per month, more often mention this. Buying several products and getting one for free is supported more by younger customers (18-25 years).

Customers are segmented into users and non-users according to TNS customer Conversion Model ${ }^{T M}$. LB stores have the highest 'ambivalent' (43\%) non-user rate as shown in a Figure 3.

In general, for $L B$ customers and non-customers one of the most important factors in the shop choice is favorable location.

For committed customers of $L B$ shops, the driving attribute is favorable store location and $L B$ shops are perceived to perform better than any other shop. Such attributes as good shopping, experience and wide range of products (alcohol and other) also matter to this group of customers. It is important to keep the same performance on these attributes and communicate them to customers.

The uncommitted customers of $L B$ shops are driven by favorable prices and store location as well as regular price campaigns and discounts (these are 3 most important factors of shop choice for them). They see Maxima being better here ( $77 \%$ of uncommitted customers of $L B$ shops have bought alcoholic beverages in Maxima during the last 3 months).

When looking at the whole alcoholic beverages retail market segmentation, overall there are not many committed customers. Rimi Hypermarket has $11 \%$, Maxima XX - $10 \%$, Rimi Supermarket $9 \%$, Maxima $X X X-7 \%$ and $L B-5 \%$ of their customers committed.

It is also important to look at open non-customers to see whether the potential customer base is large enough to work on acquiring them. Here $L B$ has the best position - it has a potential to gain $55 \%$ of the target group. Stockmann has the second position (potential to gain $49 \%$ of the target group). 


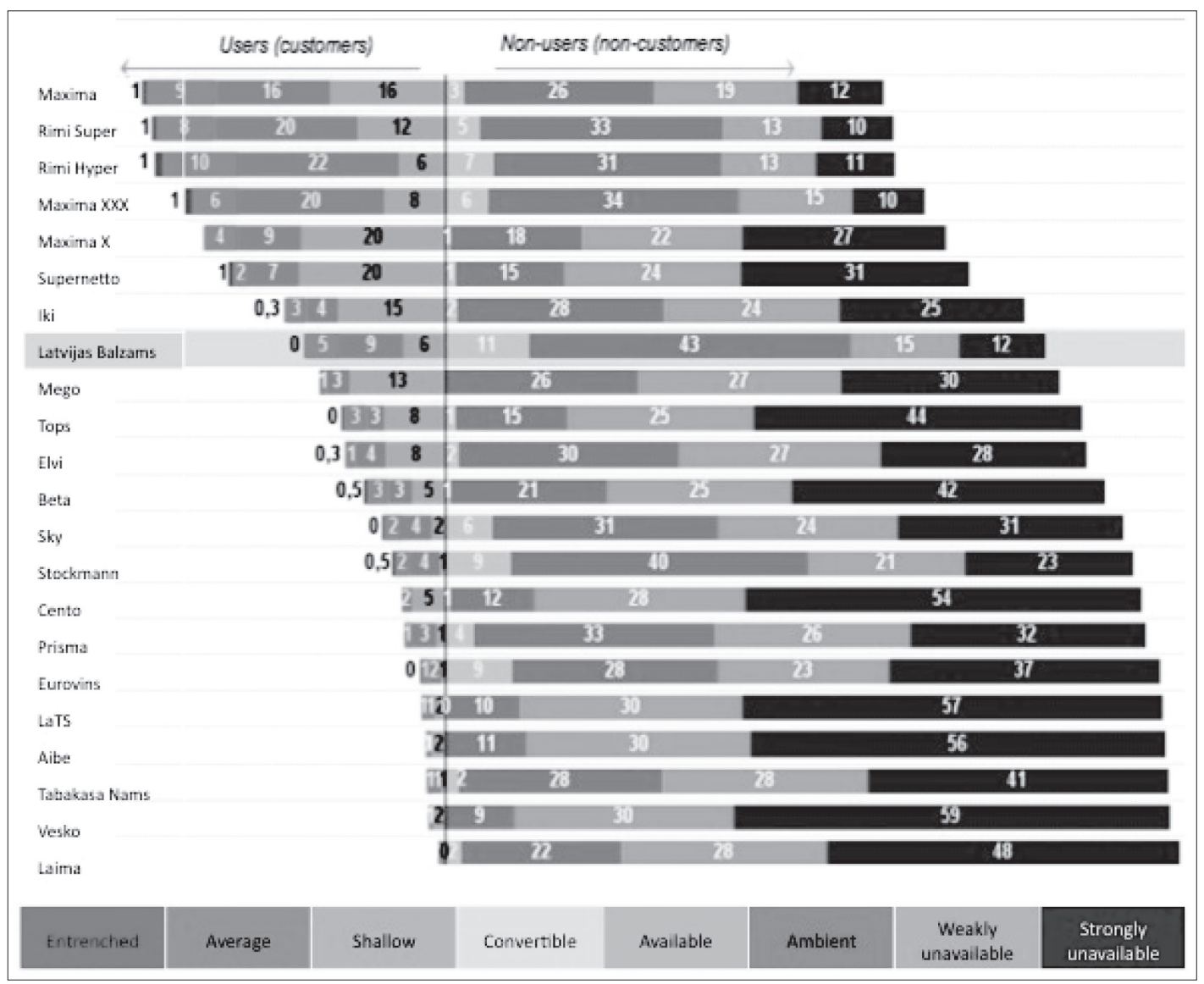

Figure 3. Overall commitment to shops of alcoholic beverages.

Source: TNS Research (2011)

From the direct competitors the best potential is for Eirovins (37\%); Tabakas Nams can attract $30 \%$ and Laima $-24 \%$ of the target group. But all 3 competitors have a very high level of strongly unavailable noncustomers - there are many people who are unlikely to switch their current shop to these.

The most important factors for committed users are favorable store location and prices as well as a shop appropriate to me as shown in Figure 4.

The open non-customers of $L B$ shops rate other shops better than $L B$ on most of attributes. $L B$ shops are perceived as having a slightly faster customer service. The most important factors for this group are favorable store location and prices as well as a shop appropriate to me. 


\begin{tabular}{|c|c|c|}
\hline \multicolumn{3}{|c|}{ Committed Users, $n=19$} \\
\hline & Index, $(\%)$ & Best \\
\hline Favorable store location & +2 & Maxima \\
\hline Good shopping experience & +8 & Maxima \\
\hline A wide range of products beyond alcohol & +18 & Eirovins \\
\hline A wide range of alcoholic beverages & +16 & Rimi \\
\hline Is a part of an urban life & +16 & Rimi \\
\hline Fast customer service & +29 & Eirovins \\
\hline Clean and orderly premises & +26 & Laima \\
\hline Kind and helpful customer service & +29 & Maxima \\
\hline A shop appropriate to me & -11 & Rimi \\
\hline Regular price campaigns and discounts & -30 & Maxima \\
\hline Attractive shop interior & +19 & Eirovĩns \\
\hline Favorable prices & .51 & Maxima \\
\hline Shop with a good reputation & -63 & Rimi \\
\hline Modern shop & $0 \%$ & Rimi \\
\hline
\end{tabular}

Figure 4. Factors Undermining Commitment to Latvijas Balzams stores Source: TNS Research (2011)

\begin{tabular}{|c|c|c|c|}
\hline \multicolumn{4}{|c|}{ OPEN NON-USERS, $n=218$} \\
\hline & Index, $\%$ & & $\begin{array}{c}\text { Best } \\
\text { Competitor }\end{array}$ \\
\hline Favorable store location & -57 & & Maxima \\
\hline A shop appropriate to me & -54 & & Rimi \\
\hline Favorable prices & .70 & & Maxima \\
\hline Regular price campaigns and discounts & -70 & & Maxima \\
\hline Shop with a good reputation & -76 & & Rimi \\
\hline Good shopping experience & -32 & & Rimi \\
\hline Is a part of an urban life & -37 & & Rimi \\
\hline Modern shop & -43 & & Rimi \\
\hline A wide range of alcoholic beverages & -20 & & Rimi \\
\hline Kind and helpful customer service & -17 & & Rimi \\
\hline Attractive shop interior & -15 & & Eirovins \\
\hline A wide range of products beyond alcohol & -6 & & Rimi \\
\hline Clean and orderly premises & -10 & & Rimi \\
\hline Fast customer service & & $+0,3$ & Rimi \\
\hline
\end{tabular}

Figure 5. Factors Undermining Commitment to Latvijas Balzams stores Source: TNS Research (2011) 
When looking at unavailable non-customers of $L B$ shops we can determine that the three key drivers are favorable store location, a shop appropriate to me and good shopping experience. At all aspects $L B$ shops lose either to Maxima, Rimi or Eirovins.

As this non-customer segment is $24 \%$ from the total target group and they know $L B$ shops, it is first important to decide if they are worth efforts (according their demography, income and expenditures on alcoholic beverages).

Qualitative study summary of alcoholic beverages store choice criteria (from high to low importance):

- Quality of alcoholic beverages (Consumers trust more in products bought in specialised stores. The majority of consumers say that beverages made by $L B$ are of high quality because they are made in Latvia, not imported. At the same time, trust in alcoholic beverages bought in supermarkets is lower due to the lack of information about suppliers);

- Prices (When choosing alcoholic beverages, consumers pay much attention to price/campaigns. Before purchasing a beverage, people check all prices and campaigns regarding the specific beverages;

- Location (Close to home, workplace or supermarket);

- Wide assortment (This is the main aspect. All categories of alcoholic beverages should be widely represented, if only the store is not specialising in one type of alcoholic beverages (wine, for example). A specialised store should satisfy everybody's needs depending on the financial state and taste of each person);

- Customer service (In a specialised store, consumers expect an advice on available beverages. However, it should not be pushy. It should be a recommendation, and consumers should be allowed to make the final decision;

- Layout of goods (A wide room; an opportunity to move freely along shelves; all products should be reachable and visible);

- Atmosphere in the trading place (Silent music (better without lyrics so that none of nationalities in Latvia had objections); no crowd; an opportunity to walk trough the store and look at beverages without hurry);

- Loyal customer card (Not mentioned spontaneously. When using a loyalty card, regular customers expect a very good price. They want to feel benefitted immediately, not by saving bonuses in a longer period);

- Parking place near the store.

Summary of an ideal specialized liqueur store is depicted in Figure 6.

\begin{tabular}{|c|c|c|}
\hline Location/Atmosphere & Service & Emotions \\
\hline $\begin{array}{l}\text { - Close to home } \\
\text { - Convenient parking } \\
\text { - Greenery outside } \\
\text { - A tourist place } \\
\text { - Modern interior } \\
\text { - Wide, light rooms } \\
\text { - Mirrors, wood in interior } \\
\text { - Everything is well visible } \\
\text { - Cleanliness } \\
\text { - Warmth } \\
\text {-Silent music } \\
\text { - Light, warmth } \\
\text { - No hurry } \\
\text { - Not crowded }\end{array}$ & $\begin{array}{l}\text {-Self-service } \\
\text { - Competent salesperson } \\
\text { - Recommendations are } \\
\text { available } \\
\text { - Personal attitude } \\
\text { - Kind, smiling salesperson } \\
\text { - Greeting } \\
\text { - Fast service } \\
\text { - Salesperson is interested in } \\
\text { helping } \\
\text { - Lower prices vs. to } \\
\text { supermarkets } \\
\text { - Wide choice } \\
\text { - Opportunity to taste } \\
\text { - Advantageous loyalty card } \\
\text { - Products for cocktails }\end{array}$ & $\begin{array}{l}\text { - Luck (a small gift) } \\
\text { - Good mood } \\
\text { - Comfort } \\
\text { - Special client } \\
\text { - Festive atmosphere } \\
\text { - Well-known, reliable, } \\
\text { domestic product } \\
\text { - Fun } \\
\text { - Reasonable prices } \\
\text { - Warmth } \\
\text { - Hospitality }\end{array}$ \\
\hline
\end{tabular}

Figure 6. An ideal specialised alcohol store: criteria summary

Source: TNS Research (2011) 


\section{Conclusions}

Factors that influence consumer's choice of a retailer differs if consumers consider specialized convenience store or specialized alcohol store. Moreover, such factors are different if compare different consumer segments depending on their loyalty to the shop or demographic profile.

Summary of learnings and strategic implications for $L B$ stores based on market trend forecast and consumer research:

- Consumers have an emotional connection (national pride) based on history of Latvijas Balzams factory and long personal experience with brands there. $L B$ name is the main reason people visit our stores - do not change brand name - as a main asset;

- Most important alcohol purchase motivator for consumers is guarantee that the product is authentic (meaning of good quality and safe) $-L B$ has a unique competitive advantage as a producer - communicate to consumers that $L B$ stores stand behind the quality and authenticity of all of the brands that $L B$ retail sell as they are produced by $L B$;

- Consumers expect $L B$ products in $L B$ stores to have an equal or lower shelf and promotion prices vs. hyper and super markets - change current price policy in $L B$ stores to match Maxima / Rimi;

- Consumer ideal location for a liquor store is close to place of residence, or place of work, on way home or near place where they buy food - reevaluate location of existing stores and create ideal map of store location based on high density living and working areas; high traffic on the way home locations; and near major hyper and super markets;

- Consumers shop at liquor stores when mainly alcoholic beverages are needed (if they also need food they shop at hyper markets) - target occasions where only alcohol is purchased and create a list of main alcohol purchase occasions with targeted communication;

- Consumers like to buy complementary goods (i.e. snacks) when buying alcohol - continue to offer complementary goods in $L B$ stores;

- Consumers expect sales people in liquor stores to be knowledgeable about wines and spirits - increase sales staff knowledge, launch practice of permanent sales stuff training program;

- Consumers like to touch the products and read the labels when choosing alcoholic brands - move from counter service to self service;

- Customers are eager to find leading competitive brands in $L B$ stores (one stop spirit shopping) - add leading competitive spirit and wine brands;

- Consumers shop at liquor stores when looking for a gift for someone - offer more gifting packs;

- Customers expect to find different assortment than hyper/ supers markets when visiting a liquor store - identify brands to be available in $L B$ stores only.

Product

- Do not change brand name - it is the main asset

- Reinforce the products in $L B$ stores come directly from the factory

- Adjust assortment based on right mix between $L B$ and leading competitive brands

- Identify brands to be available only in LB stores (i.e. limited editions)

- Adjust assortment based on right mix of complementary goods

- Add special tourist packs to assortment of stores located in old town

- Finalize LB gifting packs

Price

- Change retail price on all Latvijas Balzams products to match Maxima / Rimi

- Develop store sets based on store location and customer's purchasing power

Place

- Create ideal map of store location based on consumer preferences 
- Create a map of store location based on pedestrian traffic intensity

Promotion

- Communicate that Latvijas Balzams stores stand behind the quality and authenticity of all of its products

- Start advertising LB factory store message highlighting competitive pricing offers

- Create list of 'alcohol only purchase' occasions and target communication

- Introduce loyalty program for customers

People

- Create motivation system for store personnel linked to sales level, store performance and customer service

- All sales people need to be trained about spirits and wines including selling points for key brands

- Implement new salary policy

Process

- New retail strategy to be developed and launched

- Benefits and point of difference vs. other retailers to be communicated in a new marketing mix

- Implement self service where it makes sense

- Find most cost efficient way to implement Internet connection in stores and new IT system.

This study examined factors that influence choice of a retailer - specialized liqueur convenience store in particular. Business strategy and marketing mix was built based on the research results. Several test shops of a new concept were launched in order to examine consumer's response and make amendments in the developed strategy.

The study showed that a criterion of a liqueur store choice is very different if you consider one store or a chain, city or rural area, young or older consumers, loyal or uncommitted.

The study proved that previously made strategy without in-depth understanding of consumer preferences led to market share loss and competitive advantage weakening.

\section{References}

Aaker, D. A., Morgan, J. (1971). Modeling Store Choice Behavior. Journal of Marketing Research, Vol. 8 (February), p. 38-42.

Arnold, S. J., Oum, T. H., Tigert, D. J. (1983). Determinant attributes in retail patronage: seasonal, temporal, regional, and international comparisons. Journal of Marketing Research, Vol. 20, p. 149-157.

Bates, J. M., Gabor, A. (1987). Changes in subjective welfare and purchase behavior: A report on enquiry. Journal of Marketing Research Society, Vol. 29, No. 2, p. 183-207.

Bell, D. R., Ho, T. H., Tang, C. S. (1998). Determining where to shop: fixed and variable costs of shopping. Journal of Marketing Research, Vol. 35, p. 352-369.

Blackwell, R. D., Miniard, P. W., Engel, J. F. (2001). Consumer Behavior. 9th Edition. Harcourt, Forth Worth.

Corstens, J., Corstens, M. (1995). Store Wars, The Battle for Mindspace and Shelfspace. Wiley, Chichester.

Deaton, A., Muellbauer, J. (1980). Economics and Consumer Behavior. Cambridge University Press. London.

Engel, J. F., Blackwell, R. D., Miniard, P. W. (1995). Consumer Behavior. 8th Edition. Dryden Press. Orlando.

Euromonitor. (1986). The Changing Face of Grocery Retailing. Euromonitor. London.

Gripsrud, G., Horverak, Ø. (1986). Determinants of retail patronage: a 'natural' experiment. International Journal of Research and Marketing, Vol. 3, p. 263-272.

Hansen, M. H., Weinberg, C. B. (1979). Retail market share in a competitive market. Journal of Retailing, Vol. 55, p. 37-46.

Hisrich, R. D., Ronald, J. D., Kernan, J. B. (1972). Perceived Risk in Store Selection. Journal of Marketing Research, Vol. 9 (November), p. 435-39.

Hortman, S., McCurley, A. W., Allaway, J., Barry, M., Rasp, J. (1990). Multisegment Analysis of Supermarket Patronage. Journal of Business Research, Vol. 21 (November), p. 209-23. 
Kahn, B. E., Schmittlein, D. C. (1989). Shopping Trip Behavior: An Empirical Investigation. Marketing Letters, Vol. 1 (1), p. 55-69.

Kau, A. K., Ehrenberg, A. S. C. (1984). Patterns of Store Choice. Journal of Marketing Research, Vol. 21 (November), p. 399-409.

May, E. G. (1981). Product positioning and segmentation strategy: adaptable to retail stores? In: R. W. Stampal, E. C. Hirschman (eds.). Theory in Retailing: Traditional and Nontraditional Sources. Chicago: AMA, p. $144-153$.

Monroe, K. B., Guiltinan, J. P. (1975). A Path - Analytic Exploration of Retail Patronage Influences. Journal of Consumer Research, Vol. 2 (1), p. 19-28.

Moore, L. (1990). Segmentation of Store Choice Models Using Stated Preferences. Papers of the Regional Science Association, Vol. 69, p. 121-31.

Pessemier, E. A. (1980). Store Image and Positioning. Journal of Retailing, Vol. 56 (1), p. 94-106.

Popkowski, L., Peter, T. L., Timmermans, H. J. P. (2001). Experimental Choice Analysis of Shopping Strategies. Journal of Retailing, Vol. 77 (4), p. 493-509.

Solgaard, H., Hansen, T. (2003). A hierarchical Bayes model of choice between supermarket formats. Journal of Retailing and Consumer Services, Vol. 10, p. 169-180. Viewed online 01.08.2012 at http://tourism.wuwien.ac.at/lehrv/ lven/04ss/lv4/solgaard_hansen.pdf

Stanley, T. J., Sewall, M. A. (1976). Image inputs to a probabilistic model. Predicting Potential. Journal of Marketing, Vol. 40, p. 48-53.

Verhallen, T. M. M., de Nooij, G. J. (1982). Retail attribute sensitivity and shopping patronage. Journal of Economic Psychology, Vol. 2, p. 39-55.

Uncles, M. D., Hammond, K. (1995). Grocery Store Patronage. International Review of Retail, Distribution \& Consumer Research, Vol. 5 (3), p. 287-302.

Wrigley, N., Dunn, R. (1988). Models of Store Choice and Market Analysis. Store Choice, Store Location and Market Analysis. Neil Wrigley, Ed., New York, NY: Routledge.

\title{
I VARTOTOJUS NUKREIPTOS STRATEGIJOS SPECIALIZUOTU REGIONINIŲ PARDUOTUVIŲ TINKLUI KŪRIMAS
}

\author{
AnNa Zhigalova \\ Latvijos universitetas (Latvia)
}

\section{Santrauka}

Šiuo tyrimu siekta nustatyti, kaip turètų būti pertvarkyta specializuotų regioninių parduotuvių tinklo strategija, kad ji atitiktų vartotojų poreikius, padètų konkuruoti su kitomis parduotuvėmis ir padidintų verslo efektyvumą.

Išanalizuoti alkoholiniu gėrimų vartojimo ir pirkimo ipročiai, priežastys, parduotuvių pasirinkimo kriterijai, suvokimas, specializuotų alkoholio parduotuvių ivvaizdis bei vartotojų lūkesčiai. Taip pat išbandyta keletas verslo plètros idejų, tokių kaip asortimento keitimas ir naujos pardavimo tinklo koncepcijos vertinimas. Apklausti respondentai nuo 18 iki 60 metų, kurie pirko alkoholinius gėrimus per pastaruosius tris mėnesius. Apklausa parodè, kad vartotoju pasirinkimo kriterijai priklauso nuo progos, kuriai perkami alkoholiniai gèrimai, nustatyta ir keletas svarbių alkoholio parduotuvės kriterijų: vieta, asortimentas, perkamiausių prekių kainų lygis ir parduotuvès įvaizdis.

PAGRINDINIAI ŽODŽIAI: vartotoju elgsena, mažmeniné prekyba, strategija. 